\title{
The role of property rights in commercial agreements*
}

\author{
David Echeverry Botero** \\ Recibido: 5 de julio de 2015 - Revisado: 15 de julio de 2015 \\ Aprobado: 20 de Agosto de 2015
}

\begin{abstract}
The form of a state depends widely in the way that the state treats the property rights. 'Every definition of property has direct consequences for the question of the distribution of economic wealth and power, the role of governments and the autonomy of citizens' (Gray \& Edgeworth,2003) and so property is always a paramount issue for a State. Most of the Western countries have adopted democratic political systems and a capitalist economical system of production in where is necessary to give recognition to private property.

This paper aims to present how transfers of property take place under Common Law, focusing on personal property issues, and comparing them with other legal systems in South America that have different rules for transfer of property.

Keywords: Propery Rigths, Common Law System, Civil Law System, transference of property, agreements.

"This article was a product of the investigation made at the University of Melbourne for David A. Echeverry under the master program of Commercial law, made for the subject of Corporate Social Responsibility.

* Abogado de la Pontificia Universidad Javeriana, Magister en derecho Económico de esta misma Universidad, y Master of Commercial Law (LL.M) de la Universidad de Melbourne. Docente de la Maestría en derecho Económico de la Universidad Javeriana en las materias de Investigación científica y Seminario de investigación. Se desempeña igualmente como director de proyectos de investigación en la maestría de Derecho Contractual de la Universidad Santo Tomás, y como docente de las materias de Derecho Comercial General y Derecho Comunitario e integración económica en la Universidad Politécnico Grancolombiano. Correo Electrónico: davidaugustoecheverry@yahoo.es
\end{abstract}




\section{El PAPEL de los derechos de PROPIEDAD EN LOS CONTRATOS COMERCIALES}

\section{Resumen}

La forma de un estado influye en la regulación de los derechos de propiedad. Lo anterior en razón a que el concepto de propiedad tiene consecuencias directas sobre la cuestión de la distribución de la riqueza y el poder económico, del papel de los gobiernos y de la autonomía de los ciudadanos, lo que genera como consecuencia que la propiedad sea siempre un tema de suma importancia para un Estado. La mayoría de los países occidentales han adoptado sistemas políticos democráticos y un sistema económico capitalista de producción, en donde es necesario el reconocimiento a la propiedad privada.

Este documento tiene como objetivo presentar cómo se transfiere la propiedad se en el Derecho Consuetudinario, centrándose en cuestiones de propiedad personal, y su comparación con otros sistemas jurídicos de América del Sur que tienen diferentes reglas para la transferencia de la propiedad.

Palabras clave: Derecho de propiedad, Sistema de Derecho Común, Sistema de Derecho Civil, transferencia de la propiedad, acuerdos.

\section{O PAPEL DOS DIREITOS DE PROPRIEDA DE NOS CONTRATOS COMERCIAIS}

\section{Resumo}

A estrutura econômico-social de um Estado influencia na regulação dos direitos de propriedade. Esta é a razão para o qual o conceito de propriedade tem consequências diretas sobre a questão da distribuição da riqueza e o poder econômico, do papel dos governos e da autonomia dos cidadãos e, consequentemente, que a propriedade seja sempre um tema de extrema importância para um Estado. A maioria dos países ocidentais adotaram sistemas políticos democráticos e um sistema econômico de produção capitalista, no qual fica necessário o reconhecimento da propriedade privada.

Portanto, este artigo tem como objetivo apresentar as transferências de propriedade no Direito Consuetudinário, centrando-se na propriedade pessoal e sua comparação 
com outros sistemas jurídicos da América do Sul, que tem diferentes regras para a transferência da propriedade.

Palavras-chave: Direito de Propriedade, Sistema de Direito Comum, Sistema de Direito Civil, transferência de contratos de propriedade.

\section{Introduction:}

One of the first concepts of property was espoused by Sir William Blackstone. He defined property as 'the sole and despotic dominion which one man claims and exercises over the external things of the world, in total exclusion of the right of any other individual in the universe' (Gray \& Edgeworth, 2003).

The concepts of property have evolved, in accordance with society's principles, from the absolute dominion of a thing espoused by Blackstone (a dominion so absolute that it allows the owner to destroy the thing if he wishes; this approach generates queries about the role of property in a society and the responsibility of owners), to '[...] directs to the dominion over, or control by, a person, or legal subject, and the object' (Gray \& Edgeworth, 2003).

According to this change, property is no longer absolute as in Sir Blackstone's approach. The Law creates the rights of property, imposes limits on it, and says how can be transferred from one person to another.

Cited authors agreed with this new concept of property, so property has three main elements: first, dominion; second, exclusion; and third, external things. The first characteristic is related with the power that the law gives to the owner of a thing over the thing itself. This power includes the right to possess, to use, to manage, to receive the income generated by the thing, and to transfer the property.

The second element, exclusion, means that "private property" is not for everybody. The owner can enjoy private property by himself and preclude others from enjoying his private property or interfering with his rights.

The third characteristic is that the property should be an external object. This means that those items that are in the world (not inside me) and those items that the law says that can be owned (e.g. stocks and brands) are the subject-matter of the assignment.

Accordingly, it is important to define what it is understood as assignment under de common law: 'Assignment means the immediate transfer of an existing property 
right, vested or contingent, from the assignor to the assignee. Anything that in the eye of the law can be regarded as an existing subject of ownership, whether it be a chose in possession or a chose in action, can today be assigned [...]' (Norman v Federal Commissioner of Taxation, 1963, 24).

The Common Law ${ }^{1}$ has two coexisting systems of rules for assignment: the first system consists of the rules of transference generated by statutes; the second, consists of the rules of transference developed by the courts in Equity. These rules complement each other; when there is not applicable statute for specific agreement, it is equity who fills the gap by applying the principles of natural justice in the particular case.

Remedies used by both systems which constitutes the common law are different. If a transfer of property occurs under the Common $\mathrm{Law}^{2}$ the remedy would be one in the Common Law, and if a transfer of property occurs under the rules of equity, equity would provide the remedy. Therefore, remedies in equity and remedies in Common Law operate side by side, complementing each other guaranteeing justice in a specific case.

Finally, is important to say that this work is concerned with private property only, which is the property relevant for the commercial transactions. Public property will not be analyzed because it cannot be the subject-matter of commercial relationships.

\section{Transfer of goods under Victoria Goods Act 1958 and the Sale of Goods Act 1979 UK}

\section{Definition of the contract for sale of goods}

The primary mechanism to transfer the property is the contract for sale of goods. The other mechanisms of transfer of property (e.g. gift) are not relevant for the commerce and therefore, will not be analyzed in this paper.

The Victoria Goods Act and the United Kingdom Sale of Goods Act have similar provisions related to the definition of a contract for sale of goods 'A contract

\footnotetext{
${ }^{1}$ Common Law here is understood to involver both Common Law Rules and Equity rules.

${ }^{2}$ Common Law here is understood in a narrow way to make a division with equity.
} 
for sale of goods is a contract whereby the seller transfers or agrees to transfer the property in goods to the buyer for consideration called the price' (Goods Act, 1958, s 6).

The only difference between the two acts related to the definition, is the last part of the Victoria Goods Act 1958 that states 'There may be a contract of sale between one part owner and another' (Goods Act, 1958, s 6). However, that difference does not make a sufficient change so as to result in a different definition.

From the definition it is possible to infer three main elements necessary for the existence of the contract of sale: (i) an object, (ii) the agreement, and (iii) the price.

(I). The First element according to Gray \& Edgeworth (2003), the object, stands as the subject matter of the contract and consists of those external things which according to the law can be appropriated and, as a consequence, transferred to another person.

(II). The second element for the existence is an agreement. This means that at least two parts are required for a contract to exist, namely that being capable in doing so, express their intention to be bond to the other party, and that they act according to it (Goods Act, 1958).

(III). The third element is money or goods that the buyer has to give to the seller as the consideration for the transference of property. ${ }^{3}$ Without consideration, under the Common Law, it cannot be a contract unlike some civil law countries where there is a contractual relationship without consideration. ${ }^{4}$

\section{Sale and agreement to sell}

The default rule comes from the precedent stated in Re Wait (1926) which is recognized by the statutes (1958 and 1979). It is that 'Property passes when intended to pass (1) [w] here there is a contract for the sale of specific or ascertained goods the property in them is transferred to the buyer at such time as the parties to the contract intend it to be transferred'. This rule is applicable when no other condition is imposed by the parties; it is called a sale, and constitutes an assignment (Norman v Federal Commissioner of taxation, 1963).

\footnotetext{
${ }^{3}$ See e.g. Williams v Roffey Bros (1979) 1 All ER 512.

${ }^{4}$ See e.g. Código Civil [Civil Code] (Colombia) 1497 [author's trans]
} 
On the other hand, according to the Goods Act (1958, S 6 -S 2), when a condition is imposed by the parties, the goods are not ascertainable, or when the sale is going to take place sometime in the future, the property does not pass from one party to the other until the condition is fulfilled; the goods are ascertained or the agreed time comes. In this case the contract is not a sale but an agreement to sell.

The difference between a sale and an agreement to sell is relevant in the context of insolvency. In a sale the buyer has proprietary rights over the asset even if the seller still possesses it. Nevertheless, in an agreement to sell the buyer has only a personal right to the asset, consequently ' [...] for it is a basic policy of insolvency law to adopt the non-bankruptcy ordering of rights and thus to respect proprietary rights held by another prior to the debtor's bankruptcy' (Goode, 1987, p. 103).

It can be inferred, in law not in equity, which in an agreement to sell the asset goes into the common pool, and the buyer is treated as another creditor, but, under a sale, the asset is extracted from the common pool and law protects the property right of the buyer.

\section{a. Rules to ascertain the intention of the parties}

The statutes have rules to ascertain the intention of the parties in order to define the exact moment when the property passes from one to the other. ${ }^{5}$ This default rule operates when the parties have not said anything about when the property is transferred and are different when the contract is a sale or an agreement to sell.

In a sale of goods, the assets must be delivered and the property passes at the moment when the contract is complete, independently of the agreements about the payment or delivery (Goods Act, 1958, S23; Goods Act, 1979, S18, Rule 1).

In an agreement of sale of goods, on the Goods Act (1979, S18, Rules 2,3,4 \& 5), (1) the property is transferred when the seller delivers by fulfilling the conditions of the contract, provided that buyer is notified of the fulfillment of that condition; (2) In an agreement where the condition is the approval by the buyer of the assets or on "sale or return" the property is transferred when the buyer approves the goods by any kind of positive act that shows their acceptance (i.e., a signature). In alternative may accept the goods, in the absence of a positive act, if he keeps the assets without rejection for a reasonable time (depending of the facts) or for the

5 ' '...) it is impossible to have a title to goods, when nobody knows to which goods the title relates' Re Goldcorp Exchange Ltd (1995) 1 AC 74, Lord Mustill at 92 
time fixed in the contract to return the assets. (3) when the subject-matter of the agreement are future or unascertained goods by description the property passes to the buyer as soon as any of the parties have the goods in their power. Lastly in the Goods Act (1958, S24) \& Sale of Goods Act (1979, S19): (4) in an agreement with the reservation of right of disposal the property is only transfer when the seller's condition is fulfilled.

\section{Formalities of the contract}

\section{a. General rule}

The sale of goods contract and the agreement to sell, according with statute (Goods Act, 1958, S 8), can be done in writing or by word, or by a mix of both. The Common Law, privileging the freedom of the parties in their private relationships, has not imposed strong formalities to the contract for sale of goods as a general principle. However, despite the fact that this type of regulation is favourable to trade; it creates a problem of proving those issues related with the conditions of the contract, especially when the contract is made verbally, and subsequently have to be defined in the courts.

Still some limitations have been created to protect specific kinds of property. For example the contract of sale of land must be in writing and the transference of land must be registered to prove the ownership of the land (Transfer of Land Act, 1958; Property Law Act, 1958).

\section{b. Rules about time}

According to the Goods Act (1958, S 15) \& the Sale of Goods Act (1979, S 10), the default rule is that time is not crucial in a sale of goods contract. If the parties agreed something related with the time for accomplish duties, those stipulations are not paramount in the contract, unless the parties determine that the time is crucial.

Related with time dispositions under the statute, there is a difference in the Goods Act 1958 and the Sale of Goods Act 1979. While the Sale of Goods Act states that 'In a contract of sale "month" prima facie means calendar month' (Sale of Goods Act, 1979, S 10), the Goods Act 1958 does not have a similar rule, leaving this matter to the general rules of interpretation of the Common Law. 


\section{c. Implied terms}

Both the Goods Act 1958 and the Sale of Goods Act 1979 have implied terms related to the subject-matter of the contract. Most of these terms, in particular, are default rules depending on the intention expressed by the parties in the contract. In general the contract of sale has the following implied conditions:

'In a contract of sale, unless the circumstances of the contract are such as to show a different intention, there is- (a) an implied condition on the part of the seller that in the case of a sale he has a right to sell the goods and that in the case of an agreement to sell he will have a right to sell the goods at the time when the property is to pass; (b) an implied warranty that the buyer shall have and enjoy quiet possession of the goods; (c) an implied warranty that the goods shall be free from any charge or encumbrance in favour of any third party not declared or known to the buyer before or at the time when the contract is made' (Goods Act, 1958, S 17).

Section 12 (3) of the Sale of Goods Act contain some implied terms that operate in agreement of sale of goods when the seller or a third party has the intention to transfer the proprietary right to the assets, but does not have the whole title of property. In those cases they cannot pass more rights than those they hold and:

(4) (...) there is an implied warranty that all charges or encumbrances known to the seller and not known to the buyer have been disclosed to the buyer before the contract is made. (5) (...) there is also an implied warranty that none of the following will disturb the buyer's quiet possession of the goods, namely - (a) the seller; (b) in a case where the parties to the contract intend that the seller should transfer only such title as a third person may have, that person; (c) anyone claiming through or under the seller or that third person otherwise than under a charge or encumbrance disclosed or known to the buyer before the contract is made'.

\section{The price}

The general rule in the statutes, on the Goods Act (1958, S 13) \& Sale of Goods Act (1979, S 8), is that the parties should define the price or at least define the way the price is going to be set in the contract. If not, the default rule is that the buyer must pay a reasonable price according with the specific conditions and characteristics of the contract.

In the mentioned Acts the contract is void where the parties agree that the price of the goods is going to be determined by a third party, and that third is 
unable to do valuation; without any culpability of the parties. The statutes provide an exception in this case: If those goods or part of them have been delivered or the buyer is in recipient without determination of the price, he must pay a reasonable price depending on the circumstances of the business (S 9; S $6 \& \mathrm{~S} 7$ ).

It is not necessary that the buyer has paid the price to the seller to acquire the property rights over the assets according with the general rule for transference of property (the property passes when intended to passes). This rule involves a risk to the seller who transfers the property in the goods and has not received payment.

To mitigate that, the law gives some special rights to the unpaid seller in this case. '[...] the unpaid seller of goods as such has by implication of law- (a) a lien on the goods for the price while he is in possession of them; (b) in case of the bankruptcy of the buyer a right of stopping the goods in transitu after he has parted with the possession of them; (c) a right of re-sale as limited by this Part (...) (2) Where the property in goods has not passed to the buyer the unpaid seller has in addition to his other remedies a right of withholding delivery similar to and coextensive with his rights of lien and stoppage in transitu where the property has passed to the buyer' (Goods Act, 1958, S 46 \& Sale of Goods Act, 1979, S 39).

\section{Sale by person not the owner and Sale under voidable title}

In general, the Common Law does not allow the transfer of property by someone who is not the owner, but protects the good faith purchaser.

Therefore, when the seller does not have title to the goods that he intends to transfer, he cannot transfer a better right over the goods that the one that he truly has. According to the Goods Act (1958) and the Sale of Goods Act (1979), the agreement only generates personal rights in the buyer 'unless the owner of the goods is by his conduct precluded from denying the seller's authority to sell' (S 27; S21).

However, under a contract for sale of goods (S 23), if the seller acquired the goods under a voidable contract and he sells the assets in good faith to a buyer, provided that the defect in title had not been disclosure before the agreement, the property is correctly transferred.

Case-law rules and Equity principles to transfer the property

There is much debate about the two rules of law, statute and equity principles, in particular which would prevail in a conflict between them. This was decided 
in favor of the equity rules in the William Brandt's Sons \& Co v Dunlop Rubber Co Ltd (1905), 'the statute does not forbid or destroy equitable assignments or impair their efficacy in the slightest degree. Where the rules of equity and the rules of the Common Law conflict, the rules of equity are to prevail' (AC 454, Lord Macnaghten at 461).

In equity the general principle is that where there is not a legal title to transfer the property equity does not provide a solution. For example, '[...] under a simple contract for sale of unascertained goods no equitable title can pass merely by virtue of the sale' (Re Goldcorp Exchange Ltd, 1995, 1 AC 74, Lord Mustill at 91) because the transference of goods required the ascertainable transfer of property.

But equitable remedies exist and allow the transference of an equitable proprietary interest without all the formalities imposed by statute, i.e., when the assignor has done everything in his power to assign the interest, '[...] for equity looks to the intent not the form (Norman v Federal Commissioner of taxation, 1963, 109 CLR 9, 34), and because equity regards as done that which ought to be done provided that there is the possibility of guarantee specific performance by the court. ${ }^{6}$

The Court has said: 'the basis of specific performance lies in the equitable doctrine that personal obligations under a contract should be enforced where damages would be an inadequate remedy' (Hewett v court, 1983, 149 CLR 665 (Deane J)).

In this context, parties have the right to create in the contract charges, equitable assignments or other kind of rules related with the subject-matter of the contract. 'But the mere sale or agreement to sell or the acts in pursuance of such a contract mentioned in the code will only produce the legal effects which the code states' (Re Wait, 1926, 1 Ch 636 (Atkin LJ)).

\section{Assignment of future things}

In the assignment of future things there are two different scenarios as on the Norman v Federal Commissioner of taxation (1963, 109 CLR 9, 24); first, if the agreement or promise is a gift or if it is a contract with contestability. In the first case is necessary to consider that equity is against gifts, as a result no court in law or equity will enforce a promise to gift.

${ }^{6}$ Hewett $v$ court (1983) 149 CLR 666 (Deane J): '(...) no equitable interest at all in property can arise between parties in a contractual relationship unless specific performance of the contract itself could be decreed.' 
In the second case equity has a different answer, an agreement to sell future goods is, '[...] when made for value, construed as an agreement to assign the thing when it is acquired.' The seller's conscience is tied by his promise and the consideration agreed with the buyer, consequently, 'the prospective interest of the assignee [the buyer] is in the meantime protected by equity', and the buyer has an equitable property interest in the good as soon as the seller receives the property title of the promised good or when the goods come into existence, to the point that any Court in Equity would make the seller fulfill his promise, provided that the goods are ascertain. In those cases, such as the Holroyd v Marshall (1862, 11 ER 999, Lord Westbury at 191): '[...] the vendor becomes a trustee for the vendee' until he transfers the property.

\section{Assignment of choses in action}

Back on the Norman v Federal Commissioner of taxation case (1963, CLR 9, 26), a debt and other choses in action are not a mere expectative of a right of future things, but are existing rights themselves that can be assigned instantaneously in a contract, 'a legal right to be paid money at a future date is, I consider, a present chose in action, at all events when it depends upon an existing contract on the repudiation of which an action could be brought for anticipatory breach'.

The law evolved from the idea that choses in action, i.e. a debt, were not assignable rights, to give protection in equity to those rights and finally to a statutory recognition which regulates the assignment of choses in action ${ }^{7}$ (Property Law Act 1958, S 134). According to the same Law, this special transference of property, under the statute, (1) must be in writing, (2) requires notification to the debtor (3) and be absolute.

First, in equity is possible to assign debts or choses in action without all the formalities imposed by the statute, '[...] no formality is necessary beyond the clear expression of an intention to make an immediate disposition' even if it has or does not have contestability. In this context, the assignment is an equitable assignment enforceable in a Court of equity and can be done under a contract or a donation. (Norman v Federal Commissioner of taxation, 1963, CLR 9, 28; 30)

In this context, although statute imposes the requirement of writing in the transfer of property or a chose in action under the Common Law, in equity the

\footnotetext{
${ }^{7}$ See Norman v Federal Commissioner of taxation (1963) 109 CLR 9, 27
} 
assignment of chose in action could not be in writing and still be valid depending on the actions undertaken by the assignor. A transfer of property exists provided that the assignor makes ' $[. .$.$] a clear expression of intention to make an immediate$ disposition; that, in the absence of an applicable statutory requirement, suffices' (Halloran v Minister Administering National Parks and Wildlife Act 1974, 2006, 229 CLR 545, 569).

Therefore, when the purchase of the debt or chose in action is not in writing, the parties should search for a remedy in equity because in equity there is a valid gift of property transferable at law if the donor, intending to make, then and there, a complete disposition and transfer to the done, does all that on his part is necessary to give effect to his intention [...]' (Norman v Federal Commissioner of taxation, 1963, 109 CLR 9, 28).

Second, according to the Property Law Act 1958, the statute also imposes a duty to the parties to give notification to the debtor in writing as a requirement for the transfer of the property. In equity the lack of notification to the buyer does not invalid the assignment ${ }^{8}$ and the title is transferred. ${ }^{9}$

Third, the division of a debt into pieces and the assignment of those pieces to a third party, under a contract, is not enforceable in a court of law under the Property Law Act 1958 (Vic) s 134. The Act provides that the assignment of a debt or chose in action must be absolute as one of the requirements to do it.

Still it is possible to recover part of a debt in equity when all the people who have a part of the debt or chose in action are present in the process as the plaintiffs in order to constitute the whole debt ( Norman v Federal Commissioner of taxation, 1963, 109 CLR 9, 29-30).

\section{Unassignable property}

The benefits of a contract are a kind of property to the creditor. Since they are property, those rights can constitute the subject-matter of a transfer of property or an assignment. However, " $[\mathrm{t}$ ] he burden of a contract can never be assigned without the consent of the other party to the contract in which event such consent will give rise to a novation', (Linden Gardens Trust Ltd v Lenesta Sludge Disposal Ltd,

\footnotetext{
${ }^{8}$ See Grey v Australian Motorist E General Insurance Co Pty (1976) 1 NSWLR 669, Glass JA at 672

${ }^{9}$ See Norman v Federal Commissioner of taxation (1963) 109 CLR 9
} 
1998, 1 AC 85, Lord Browne-Wilkinson at 316 - 324) and the obligations can only be assigned in some circumstances.

According with the actual law about the assignment of a debt or chose in action, set in Linden Gardens Trust Ltd v Lenesta Sludge Disposals, the court decided that a contract as a whole cannot be the assigned, but the benefits of the contract can be the subject-matter of a valid assignment.

Also, any assignment of a part of a contract will depend on the contract itself, and the limitations or freedoms that the parties conceded to each other. In this context, '[...] an assignment of contractual rights [benefits or obligations] in breach of a prohibition against such assignment is ineffective to vest the contractual rights in the assignee' (Linden Gardens Trust Ltd v Lenesta Sludge Disposal Ltd, 1998, 1 AC 85, Lord Browne-Wilkinson at 319).

The assignment of obligations depends on whether the obligation is intuitu personae or not. In the intuitu personae obligation the special characteristics of the debtor matters in the contract and, because of that, it is not possible to transfer it or make any kind of assignment of that obligation to another person. ${ }^{10} \mathrm{In}$ contrast, if the obligations in the contract are not intuitu personae, does not matter who is the debtor because '[...] It is a matter of indifference to the contracting party for whose benefit is imposed ${ }^{11}$ therefore the obligation can be transferred.

\section{Penalties}

Equity does not come to the aid of the losses of a party in a contract nor to aid him when a contractual sanction has been imposed, unless the behavior of one of the parties or the imposition of the penalty can be considered unconscionable (Linden Gardens Trust Ltd v Lenesta Sludge Disposal Ltd, 1998, 1 AC 85, Lord Browne-Wilkinson at $99-117)$.

The freedom of contract in the Common Law has an implied presumption that the parties know what is best for them and, consequently, they are going to negotiate in their best interest. This principle of law coexists with the maxim that '[...] equity will relieve against an unconscionable exercise of legal rights' ${ }^{12}$.

\footnotetext{
${ }^{10}$ Don King Productions Inc. v Warren (2000) Ch 291, Lightman J at 316-324, 318

${ }^{11}$ Linden Gardens Trust Ltd v Lenesta Sludge Disposal Ltd (1998) 1 AC 85, Lord Browne-Wilkinson at $99-117$

${ }^{12}$ Stern v McArthur (1988) HCA 51; (1988) 165 CLR 489, 755
} 
Therefore is necessary to prove that, in a contract or an agreement to sell, the behaviour of one of the parties was wrong or unconscionable to obtain relief against a penalty, especially when a contract has been rescinded as a consequence of a breach of its contractual terms.

Also, a party, committing a breach of contract, who makes a claim in equity seeking the relief from forfeiture, conceived as a mortgage to ensure the payment, first has to prove that he is able to pay the value of the due plus the interest, damages and expenses (Stern v McArthur (1988) HCA 51; (1988) 165 CLR 489, 755).

Finally, in the same authority was established that if the subject-matter of the contract is land or something that has a significant value or something which is very important for the buyer, the purchaser has an equitable interest in the asset after the agreement and before the transfer of the property. Consequently the seller is considered, in equity, a trustee.

\section{Trusts and transfer of property}

a. Trusts

As it is seen in Westdeutsche Landesbank Girozentrale v Islington Borough Council (1996 AC 669), the trust is a legal fiction in which one party (express or implied trust) or the Law (constructive trust) transfers property in an asset to another with a specific purpose known by the trustee, without contestability, and with the duty to transfer that asset to a beneficiary. Constructive trust will be analyzed further in this paper.

The express trust according to Swadling (2000) is the one that emerges from the express will in doing so by the parties, but, in a difference with some civil legal systems, it is not a contract because no contestability is present. The resulting trust arises in two events: First '(A) Where A makes a voluntary payment to B or pays (wholly or in part) for the purchase of property which is vested either in $B$ alone or in the joint names of $A$ and $B$, there is a presumption that $A$ did not intend to make a gift to $\mathrm{B}$ : the money or property is held on trust for $\mathrm{A}$ (if he is the sole provider of the money) or in the case of a joint purchase by $\mathrm{A}$ and $\mathrm{B}$ in shares proportionate to their contributions' (Westdeutsche Landesbank Girozentrale v Islington Borough Council [1996] AC 669, Lord Browne-Wilkinson at 702-716 708 ). 
Second, under the same authority cited above, the resulting trust emerges '(B) Where A transfers property to B on express trust, but the trust declared does not exhaust the whole beneficial interest'.

It cannot be a trust without the knowledge of the trustee because is necessary that the trustee's conscience is affected, as set under Westdetuchevlandesbank case. As well, the property subject-matter of the trust must be identifiable, unless, under a constructive trust the benefit received by the trustee from the breach of a fiduciary duty is an unidentifiable property (Westdeutsche Landesbank Girozentrale v Islington Borough Council [1996] AC 669, Lord Browne-Wilkinson at 702-716 708).

One of the most important characteristics of the trust is that

Once a trust is established, as from the date of its establishment the beneficiary has, in equity, a proprietary interest in the trust property, which proprietary interest will be enforceable in equity against any subsequent holder of the property (whether the original property or substituted property into which it can be traced) other than a purchaser for value of the legal interest without notice. (Westdeutsche Landesbank Girozentrale v Islington Borough Council [1996] at 705)

This characteristic has two important consequences in law: (1) the asset held by the trustee, in case of the trustees insolvency, does not go to the common pool or guarantee any of the trustee's debts as a consequence of the buyer's equitable property right (Goode, 1987, 103; see also Swadling, 2000); (2) the trustee will be responsible for the asset to the extent that any transference of the asset to third parties can be traced by the beneficiary into whomsoever's hands from the date when the trust is conform and even if the asset is mixed with the property of the trustee.

When the traceable asset is money, firstly, it is necessary to establish the existence of a breach of a fiduciary duty to have an equitable property interest over the money (Westdeutsche Landesbank Girozentrale v Islington Borough Council, 1996, AC 669).

Secondly, the trace is possible only when the Court, as a remedy, deems the existence of a constructive trust which implies an equitable property interest and then is possible to trace the money even if the asset is mixed with the property of the trustee (Westdeutsche Landesbank Girozentrale v Islington Borough Council, 1996, AC 669). 
Nevertheless, according to Swadling, equity also protects the bona fide purchaser. When the asset is transferred from a trustee who breached his fiduciary duty to a bona fide third party, is not possible to take that asset away from the buyer since equitable property rights '[...] are destroyed if the res in question passes to a bona fide purchaser of the legal estate for value and without notice of the prior equitable interest'(2000, Para 4.234).

Finally, there cannot be a division between legal and equitable rights that the owner has in property, 'the legal title carries with it all rights. Unless and until there is a separation of the legal and equitable estates, there is no separate equitable title (Para 4.234).

\section{b. Constructive trust, fiduciary relationship and equitable property interest}

As stated by Swadling (2000), constructive trust is a trust created by the law, independently of the consent of the parties, as an equitable remedy attached to property when between the parties there exists a fiduciary relationship, but not limited to those cases where a fiduciary relationship exists '[i]t is a judicial remedy giving rise to an enforceable equitable obligation: the extent to which it operates retrospectively to the prejudice of third parties lies in the discretion of the Court' (Muschinski v Dodds (1985) 160 CLR 583, Deane J 614).

A fiduciary relationship, in equity, as stablished in Muschinski, exists when one of the parties represents that he is acting in the other party best interest, i.e., the law says that the relationship in the contract between the lawyer and their client, company directors and shareholders, agent and principal and the parties in a joint venture (partnership) are species of fiduciary relationships.

In the same authority was set that the party whom is acting in the other's best interest has a fiduciary duty by which cannot make a profit at the expense of the beneficiary, unless the beneficiary consents to it. Also the trustee cannot act if they have a conflict of interest. Therefore if, under a breach of a fiduciary duty, the trustee receives a benefit, the beneficiary has an equitable property interest in that asset (Muschinski v Dodds (1985) 160 CLR 583, Deane J 614).

Equity gives two main remedies to the beneficiary whom suffers from a breach of fiduciary duty: (1) grants a proprietary interest in the profits made by the trustee which, under the breach of a fiduciary duty, makes a profit; (2) creates a constructive trust between the parties in which the party who breaches their fiduciary duty 
becomes a trustee for the other party, and has the obligation to transfer the asset to the beneficiary for whom they hold an equitable property interest over the asset (e.g. the profits made by company, the money received by a lawyer on behalf of client, agent that receives something on the behalf of the principal etc.) (Muschinski v Dodds (1985) 160 CLR 583, Deane J 616).

\section{Transfer of property in some Civil Law countries in South America}

The rules for transfer property in common Law and in civil Law countries are similar. However, the particularities of each system could generate frustrated expectations of property rights after a contract is complete, especially when one of the parties comes from a Common Law system. For that reason is important to make a description of transfer of property rules under Civil Law, pointing some of the small differences that can generate misunderstandings in international commerce.

The main difference for transference of property in the Common Law and in Civil Law is that, in the first one, the property is transfer with the title and the delivery is not a requirement for transfer the asset. In contrast, in Civil Law the delivery is a requirement for transfer property. This difference can increase the transactional cost because of the asymmetry of the information known by the parties.

In Colombia, Chile, Peru and most of the Civil Law countries there is not equity (understood as a system of rules) and only statute determines the transfer of property. Therefore, not equitable propriety interest exists under Civil Law system neither equitable remedies i.e. constructive trust.

\section{Personal Rights and property (an specie of In Res Rights)}

Similarly with the Common Law, Civil law countries based their property law on the difference between personal and in res rights. In the Colombian Código Civil [Civil Code] the personal rights are those kinds of rights that are enforceable only to the person who has acquired a legal obligation under a contract or by virtue of the law, an obligation to transfer property, to do something, or to not do something. This kind of right gives the holder a personal action in which all the assets of the debtor are guaranteed in the non-compliance.

In contrast in the Código Civil [Civil Code] form Perú, in res rights (which are created only by law), the right holder has a direct right over the asset and does not 
need an act or omission of another person to enjoy their right. The law imposes an implied duty on everybody to respect the right of the owner (general obligation of omission), therefore, the in res right is erga omnes (enforceable to everybody). ${ }^{13}$

The most important in res right is ownership. Ownership, similar to the Common Law, is an in res right in property that allows the owner to use and enjoy the object, exclude others for use of the object, receive any benefit that the property can produce (e.g. the apples of an apple tree, or the rent of a house), transfer the property and to trace the object into whosoevers hands it is held (ius persequendi).

In a difference with the Common Law system, in Colombia, Civil Law has reivindicatio that allows the owner to recover their property when the possession is held by someone else with or without a valid title. This action protects property against the possessor and only protects the owner of the thing (Civil Code, art 669; 946).

As the Common Law, Civil Law has a prohibition that property rights must respect Law and other's rights, not being absolute.

It is not correct under a Civil Law system to affirm that there is ownership on personal rights in contrast with the Common Law system where is correct to speak of kinds of property over some personal rights (i.e. benefits of a contract). As stated by Ospina (2008), the right holder has or has not a personal or in res right but he does not own a right under Civil Law systems.

\section{Transference of property}

In some Civil Law Countries ${ }^{14}$ for example Colombia, Chile and Perú, for transfer property three things are required, in a difference with the Common Law which only the title is required: First, the existence of the sources of obligations; second, the title that created the obligation in a contract or agreement; and third, the modus that is a further step, after the contract, that the parties have to do in order to transfer the property.

Two kinds of goods can be owned in the case of the mentioned countries: (1) all external existing things that can be perceived by the senses, and (2) those things that cannot be perceived by the senses as the brands of shares.

${ }^{13}$ See also Ospina Guillermo 'Régimen general de las obligaciones' (2008) Octava Edición, Temis ed, 18 [author's trans]

${ }^{14}$ See e.i. Código Civil [Civil Code] (Colombia) [author's trans]; Código Civil [Civil Code] (Chile) [author's trans]; Código Civil [Civil Code] (Perú) [author's trans] 


\section{a. The source of the obligation}

The source of the obligations in those countries are the (1) the unilateral duty when a person obliges himself to do something, (2) an offense which is when somebody causes (with or without intention) harm to another and has the duty to repair it, (3) unjust enrichment which creates a duty to return the received asset, (4) the law which imposes obligations on the people, and (5) the contract or agreement.

\section{b. The title or contract}

The most relevant source to transfer property under Civil Law, as it is in the Common Law system, is an agreement between two or more parties that generates personal rights and duties among themselves (Ospina, 2008). In the Colombian case, the contract, when is complete, is rule of law to the parties and cannot be breached or terminated before completion unless the parties agree or a judge declares it. Otherwise it must be performed in good faith (Colombia Civil Code, art 1603).

One of the main differences with the Common Law is that the contract, in Civil law systems like Chile and Perú, does not need contestability to be construed as a contract.

In these two countries to transfer property it is necessary that the contract constitutes a transfer of domain title accordingly to the law (art 745). This means that the contract must have an obligation to transfer the asset; transference implies the protection of the goods until it is transferred to the party (art 1605).

Now, in Colombia and Chile the obligation to transfer property under a contract can be subject to an uncertain condition (uncertainty of happening) (Art 1530; Art 1473) or certain condition (its occurrence is matter of time) (Art 1551; Art 1494). If it is an uncertain conditional obligation for the future transfer of property, the obligation does not exist until the condition happens. But, if the transfer is subject to the non-occurrence of something, the obligation exists but ceases when the condition happens. In contrast the certain conditional obligation always exists (because its certainty) but its enforceability depends on the condition (Art 1551; Art 1494).

\section{c. Contract to sale}

A contract of sale is an agreement where one of the parties (the seller) has the obligation to transfer an asset to another (the buyer) in exchange of a price. ${ }^{15}$

${ }^{15}$ Código Civil [Civil Code] (Colombia) art 1849 [author's trans]; Código Civil [Civil Code] (Chile) art 1793 [author's trans]; Código Civil [Civil Code] (Perú) art 1529 [author's trans] 
The Contract of sale has default rules that apply to all the other contracts to transfer the property. It is important to note that the two main titles (contracts) for transfer of property are a contract of sale and a donation. According to Ospina (2008), the difference between those two contracts is that in the first one the transference of property is realized with contestability and the second, being a contract, the transference is made as a gift.

The default rule is that a contract of sale has no further formalities than agreement as to the asset and the price, although the transfer of property does not occur until the parties achieve the modus, so the title is not enough (art 1857 Colombian Civil Code). And so it can be in writing or verbally. However, when the asset to be transferred is land the contract must be in writing and the title must be registered to be valid in law (Código Civil [Civil Code] (Colombia) art 1849 [author's trans]; Código Civil [Civil Code] (Chile) art 1793 [author's trans]; Código Civil [Civil Code] (Perú) art 1529 [author's trans]).

The subject-matter of a contract for sale of goods can be: identified things or general things. In the first case the obligation can only be fulfilled with the object described in the agreement and not with anything else, and if the asset is destroyed, the obligation ceases with it and any culpability is satisfied with compensation. In the second case, the obligation can be fulfilled with any similar asset and if the object is destroyed the obligation is still alive and enforceable (Código Civil [Civil Code] (Colombia) art 1849 [author's trans]; Código Civil [Civil Code] (Chile) art 1793 [author's trans]; Código Civil [Civil Code] (Perú) art 1529 [author's trans]).

In the case of a contract for sale over a future thing, the law understands that it is a conditional obligation and the condition is the existence of the asset, unless the parties make a different agreement. But if the subject-matter of the contract is an asset that the parties supposed that exists and it does not, the contract does not produce any effect.

A contract for sale of goods over an asset that does not belong to the seller is valid and has an implied condition that the seller will obtain the thing and transfer it to the buyer, or else pay compensation. ${ }^{16}$

${ }^{16}$ Código Civil [Civil Code] (Colombia) 1871 [author's trans]; Código Civil [Civil Code] (Chile) art 1815 [author's trans]; Código Civil [Civil Code] (Perú) art 1537 [author's trans] 


\section{d. Modus of transference}

In Colombia, Chile and Peru there are as many titles or contracts as the parties can create or imagine under commercial freedom. Nonetheless, the modus (or the way to transfer) that complement the title and determine when the property passes from one party to another are only those which the law have created for that effect. ${ }^{17}$

This is particularly important under insolvency cases. Under the Common Law as said before, after the contract for sell is completed, the asset does not go into the common pool. In some Civil Law systems, ${ }^{18}$ the asset, even with a complete contract of sell, goes into the common pool unless the parties have done the modus before the insolvency of the debtor.

The modus are occupation, accession, succession due to death, prescriptio and traditio.

First, similar with the Common Law, occupation is the modus to acquire the property over those things that belong to nobody (res nullius) or abandoned property. It operates when the asset is in the control of the new owner. ${ }^{19}$

Second, accession is the modus in which the owner of a thing also becomes the owner of those things that the thing produces or are permanently attached to it (the proprietor is defined by the importance of the property, where the proprietor of the most important asset becomes owner of the attached thing). It operates as soon as the thing produces something or something is attached to the property. ${ }^{20}$

Third, succession due to death functions when someone dies and their goods are transferred, by virtue of the law, to their heirs as soon as the legal process to do that is complete.

Fourth, prescriptio is the way to acquire property when the possessor holds it for a period of time according to the law. ${ }^{21}$

Finally, tradition (similar figure to the delivery in the Common Law) is the modus where the old owner, (i) by himself or using an agent, (ii) delivers the asset

${ }^{17}$ Until the modus is done the asset is guarantying all the creditors debts and there is not special protection in case of insolvency. Ibid See Also Ospina Guillermo 'Régimen general de las obligaciones' (2008) Octava Edición, Temis ed [author's trans]

${ }^{18}$ See i.e. Colombia, Chile and Peru

${ }^{19}$ Ibid art 685; Código Civil [Civil Code] (Chile) art 606 [author's trans]; Código Civil [Civil Code] (Perú) art 929 [author's trans]

${ }^{20}$ Ibid art 713 and 729; Código Civil [Civil Code] (Chile) art 643 [author's trans]; Código Civil [Civil Code] (Perú) art 938 [author's trans]

${ }^{21}$ Ibid art 753; Código Civil [Civil Code] (Perú) art 950 [author's trans] 
described in a contract (contract which has in it transference of property obligations) to the new owner, accomplishing the specific law formalities ${ }^{22}$ (iii) without any mistake in the identification of the thing or in the conditions of the agreement, ${ }^{23}$ (iv) with the intention to assign the property whether the contract has contestability or not, and if it has contestability whether paid or not the price, and (vi) the new owner has the will to accept it. ${ }^{24}$

Traditio can transfer property under a certain or uncertain condition. When the condition is limiting the traditio, no delivery can be done until the condition occurs. If the condition is that the property is transfer until something happens, the property passes, but must be returned at as soon as the condition happens. ${ }^{25}$

There are different rules to ascertain traditio under Civil Law system that does not exist in the Common Law. When the asset is moveable (things that can move by itself) delivery is done when (i) the new owner has the object in his control, or (ii) the thing was shown to the new owner, (iii) the new owner gives the keys or guarantees access to the other party to the place where the object is stored, (iv) the old owner takes charge of putting the object in the agreed place, or (v) between the person who possesses the thing but is not the owner and the owner of the thing arise an agreement to transfer the thing. ${ }^{26}$

When the asset is an unmovable good traditio takes place when the registration of the title is performed in the governmental office provided to those issues. ${ }^{27}$ Finally, traditio of personal rights is completed by delivering to the other party the title where the right is. ${ }^{28}$

\section{Conclusions}

'Property is always a reflection of some of the most deeply held values in society. This is unsurprising, given that the property is the institution which determines the precise nature and distribution of the means of production, consumption and

\footnotetext{
${ }^{22}$ Ibid art 747

${ }^{23}$ Ibid art 746

${ }^{24}$ Ibid art 740

${ }^{25}$ Ibid art 750

${ }^{26}$ Ibid art 754

${ }^{27}$ Ibid art 756

${ }^{28}$ Ibid art 761
} 
exchange; in doing so, it is also the primary determinant of wealth and the means of sustenance, and much more besides.' (J. Gray and B Edgeworth, 'property law in New South Wales' (LexisNexis Butterworths, 2003) Ch1 p 2)

In the same way, the property, being the base of all the western country's economies, is the base for the commerce since the traders of goods can only transfer the property of something that they have legal title over.

The different law systems existing in the countries that trade impose different rules to the transference of property. This could generate problems in commerce and in international commercial agreements under complex systems of production and trade that have been developed as a consequence of globalization.

\section{Reference List}

Código Civil [Civil Code] (Colombia) [author's trans]

Código Civil [Civil Code] (Chile) [author's trans]

Código Civil [Civil Code] (Perú) [author's trans]

Don King Productions Inc. v Warren (2000) Ch 291, Lightman J at 316-324.

Durham Bros v Robertson. (1898). 1 QB 771.

Fair Trading Act 1999 (Vic).

Fair Trading Amendment (Unfair Contract Terms) Act 2010 (Vic).

Fair Trading Amendment (Australian Consumer Law) Act 2010 (Vic).

Goode, R.M. (1987). 'Ownership and Obligation in commercial Transactions', 103 The Law Quarterly Review.

Goods Act 1958 (Vic).

Gray, J. \& Edgeworth, B. (2003). 'Property law in New South Wales'. LexisNexis Butterworths.

Grey v Australian Motorist \& General Insurance Co Pty (1976) 1 NSWLR 669, Glass JA.

Hewett v court (1983) 149 CLR 666 (Deane J).

Holroyd v Marshall (1862) 11 ER 999, Lord Westbury.

Halloran v Minister Administering National Parks and Wildlife Act 1974 (2006) 229 CLR 545.

Linden Gardens Trust Ltd v Lenesta Sludge Disposal Ltd (1998) 1 AC 85, Lord BrowneWilkinson at $99-117$.

Muschinski v Dodds (1985) 160 CLR 583, Deane J 614.

Norman v Federal Commissioner of taxation (1963) 109 CLR 9, 24.

Ospina, G. (2008). 'Régimen general de las obligaciones'. Octava Edición, Temis ed. 
Property Law Act 1958 (Vic).

Re Goldcorp Exchange Ltd (1995) 1 AC 74, Lord Mustill.

Re Wait (1926) 1 Ch 635 (Atkin Lj).

Sale of Goods Act 1979 (UK).

Sale of Goods Amendment Act 1995 (Vic).

Stern v McArthur (1988) HCA 51; (1988) 165 CLR 489, 755.

Swadling, W. (2000). 'Property: General Principles' in P Birks (ed), English Private Law. Vol 1

Tanward Enterprises Pty Ltd v Cauchi (2003) HCA 57; 217 CLR 315; 201 ALR 359; 77 ALJR 1853 (7 October 2003).

Transfer of Land act 1958 (Vic).

Westdeutsche Landesbank Girozentrale v Islington Borough Council [1996] AC 669, Lord Browne-Wilkinson at 702-716, 705.

Williams v Roffey Bros (1979) 1 All ER 512.

William Brandt's Sons \& Co v Dunlop Rubber Co Ltd (1905) AC 454, Lord Macnaghten.

Worthington, S. (2002). 'The proprietary Consequences of Rescission'. Restitution Law Review 28. 